\title{
Philosophical Understanding of Music and Poetry in Sufism
}

\author{
Alfiia K. Shayakhmetova* \\ Dmitry Hvorostovsky Siberian State Academy of Arts \\ Krasnoyarsk, Russian Federation
}

Received 10.10.2021, received in revised form 10.12.2021, accepted 18.01.2022

\begin{abstract}
The role of music and words in Sufi practice is very high. It is through the musical component and the sounding word that the main attributes of the mystical direction in Islam are given, becoming a powerful sacred instrument in comprehending the truth.

Sufism is a philosophical, aesthetic, religious, ethical doctrine and lifestyle. In the past, it had embraced all spheres of social life, influenced, and often determined the creative thinking of poets, musicians, architects, artisans, and other creators. Nowadays Sufism is an active practice of religious life in an unorthodox Islam. It is becoming a source of inspiration for contemporary composers and poets.

Many ideas of Sufism were in conflict and opposition with the official line of the orthodox faith. Among these ideas was music, for which the Sufis use the term «sama» (literally «listening»). In Sufism, music as one of the ways to comprehend God, had special power. This study presents the theoretical aspect of the music and poetry influence on the aesthetic side of Sufism. Based on the research of Islamic scholars, and most importantly on the literary, philosophical works of the Sufis, previously not used with scientific intentions; Let us present a picture of the vision and understanding of the musical and aesthetic side of unorthodox Islam. It is also important to rediscover the relationship between the emergence and introduction of the musical aesthetics of Sufism into the modern musical ritual practice of an unorthodox Islam.
\end{abstract}

Keywords: treatises of medieval oriental thinkers, music, poetry, philosophy of Sufism, ritual «sama».

Research area: art history.

Citation: Shayakhmetova, A.K. (2022). Philosophical understanding of music and poetry in sufism. J. Sib. Fed. Univ. Humanit. soc. sci., 15(1), 103-114. DOI: 10.17516/1997-1370-0880

\footnotetext{
(C) Siberian Federal University. All rights reserved

* Corresponding author E-mail address: alfiya007@list.ru ORCID: 0000-0002-0646-3896
} 


\title{
Философское осмысление музыки и поэзии в суфизме
}

\author{
A.K. Шаяхметова \\ Сибирский государственный институт искусств \\ имени Дмитрия Хворостовского \\ Российская Федерачия, Красноярск
}

\begin{abstract}
Аннотация. Роль музыки и слова в суфийской практике весьма высока. Именно через музыкальный компонент и звучащее слово подаются основные атрибуты мистического направления в исламе, становясь могущественным сакральным инструментом в постижении истины.

Суфизм - это философская, эстетическая, религиозно-этическая доктрина и образ жизни. В прошлом он пронизывал все сферы общественной жизни, влиял, а часто и определял художественное мышление поэтов, музыкантов, архитекторов, ремесленников, представителей других творческих профессий. Сегодня суфизм действующая практика религиозной жизни в неортодоксальном исламе. Он становится источником вдохновения для создания музыкальных и поэтических произведений для современных композиторов и поэтов.

Многие идеи суфизма находились в противоречии и оппозиции с установками официальной веры. В их число попала и музыка, обозначаемая у суфиев термином «сама» (буквально «слушание»). В суфизме особой силой наделялась музыка, которая служила одним из способов постижения Бога.

В данном исследовании представлен теоретический аспект проблемы влияния музыки и поэзии на эстетическую сторону суфизма. Опираясь на информацию, почерпнутую из исследований ученых-исламоведов, а главное на литературные, философские труды суфиев, ранее не использованные в научном обороте, представим картину видения и понимания музыкально-эстетической стороны неортодоксального ислама. Также важно заново открыть взаимосвязь возникновения и внедрения музыкальной эстетики суфизма в современную музыкальную обрядовую практику неортодоксального ислама.
\end{abstract}

Ключевые слова: трактаты средневековых восточных мыслителей, музыка, поэзия, философия суфизма, обряд «сама».

Научная специальность: 17.00.00 - искусствоведение; 17.00.02 - музыкальное искусство.

Введение. Изучение суфизма сегодня рассматривается с различных позиций. Но работы, раскрывающие основы философской концепции искусства (поэзии и музыки) в суфизме, фрагментарны и освящают суфризм не в полной мере. Музыка в контексте суфийской практики представлена в исследованиях Е.А. Бертельса (Bertel's, 1965), C.X. Hacp (Nasr, 2009), А.А. Хисматулина (Khismaulin, 1999), К. Эрнста (Ernst, 2002). Г.Б. Шамилли (Shamilli, 2020) рассматрива- ет философию музыки в целом исламского мира X-XV веков. Л.И. Манько (Man'ko, 2010) представляет эстетику суфизма на примере деятельности мыслителя-суфия современности Хазрата Инайята Хана.

А. Курбанмамадов (Kurbanmamadov, 1987) предпринимает попытку раскрыть эстетическую сущность суфизма. В мусульманской среде это учение было достаточно распространенным. Анализ глубинных сакральных философских, этических 
истин суфизма до настоящего времени требует осмысления сквозь призму современного социокультурного пространства. М. Т. Степанянц (Stepaniants, 1987) говорит о суфизме как о варианте мусульманского «возрожденчества», где ориентир направлен именно на поиск внутреннего человеческого ресурса для традиционного общества, которое испытывает необходимость в аксиологических ориентациях.

Сегодня имеется ряд переведенных на русский язык трактатов таких мыслителей, как Абдуррахман Нураддин ибн Ахмад Джами, Дервиш Али Чанга, Абу Бакр Ибн-Араби, Джавад Нурбахш, Имадеддина Насими, Джалаладдин Руми, Омар Хайям, Хамза Фансури, Хушхал-хан Хаттак. Именно эти работы станут основой для нашего анализа музыкально-эстетической стороны суфийской практики.

Возникновение суфизма. Исторические корни суфизма уходят в VII век (время становления мусульманства) и тесно переплетаются с первыми проявлениями аскетической тенденции в исламе. Суфизм насчитывает более десяти веков своей истории и распространен по всему мусульманскому миру. Для каждого региона (Средней Азии, Азербайджана, Ирана, арабских стран, Индии, Турции и др.) характерны свои суфийские ордены. Такое многообразие не вело к распаду суфизма. Целостность суфизма заключалась в наличии у него общих, единых мировоззренческих, философских принципов и постулатов, сходной ритуально-обрядовой практики, взаимосвязанности и взаимовлияния орденов и общин. Обязательным для всех разновидностей орденов и учений считался путь самосовершенствования суфия, заключающийся в постижении абсолюта, истины, слияния и растворения в ней.

Это было время значительного территориального расширения арабского государства и стремительного обогащения верхушки арабского социума путем военных завоеваний. Но с точки зрения мусульманской нравственности богатство было грехом, если оно становилось целью существования. Именно негативное от- ношение к богатой верхушке арабского социума создало почву для формирования мистико-аскетических настроений, отразивших процесс резкого социального расслоения арабского общества. Аскеты были против алчности арабской аристократии, ее чрезмерного увлечения роскошью, противопоставляя ей идеалы раннего ислама в стремлении утвердить подлинные духовно-нравственные ценности религии.

Как самостоятельное течение внутри ислама суфизм выделяется в IX-X веках. Его становление было сопряжено с ростом авторитета научной философской мысли и с усилением свободомыслия. Многие представители суфизма явились авторами трактатов, стихотворений, раскрывающих в научной или художественной форме догматы нового учения. В XIII веке складываются специальные образовательные центры во главе с наставником, а в XV веке появляются суфийские ордены, дисциплинарный порядок которых предполагал полное подчинение верующего шейху. Он направлял своих учеников в нужное русло и проповедовал, раскрывал смысл Священного писания.

На раннем этапе своей истории аскеты собирались вместе для чтения Корана и размышления мистических настроений. Тогда мистицизм существовал в одном контексте с ортодоксальным исламом, так как основная цель в постижении божественных истин была одинакова. Между тем представители ортодоксального ислама и феодальной верхушки вели постоянную борьбу против мистических крайностей суфизма, в которых обозначились отступления от некоторых вероучительных догматов ислама и игнорирование установлений шариата.

Понимание музыки в трактатах средневековых восточных мыслителей. Осмысление философских проблем суфизма было представлено в трактатах мыслителей. В этом русле возникает вопрос о дозволенности музыки («сама») и танца (ракс) в ритуалах суфиев. Пик полемики приходится на X-XI века, когда появляется ряд крупных сочинений по теории и практике суфизма, принадлежащих выдающимся представите- 


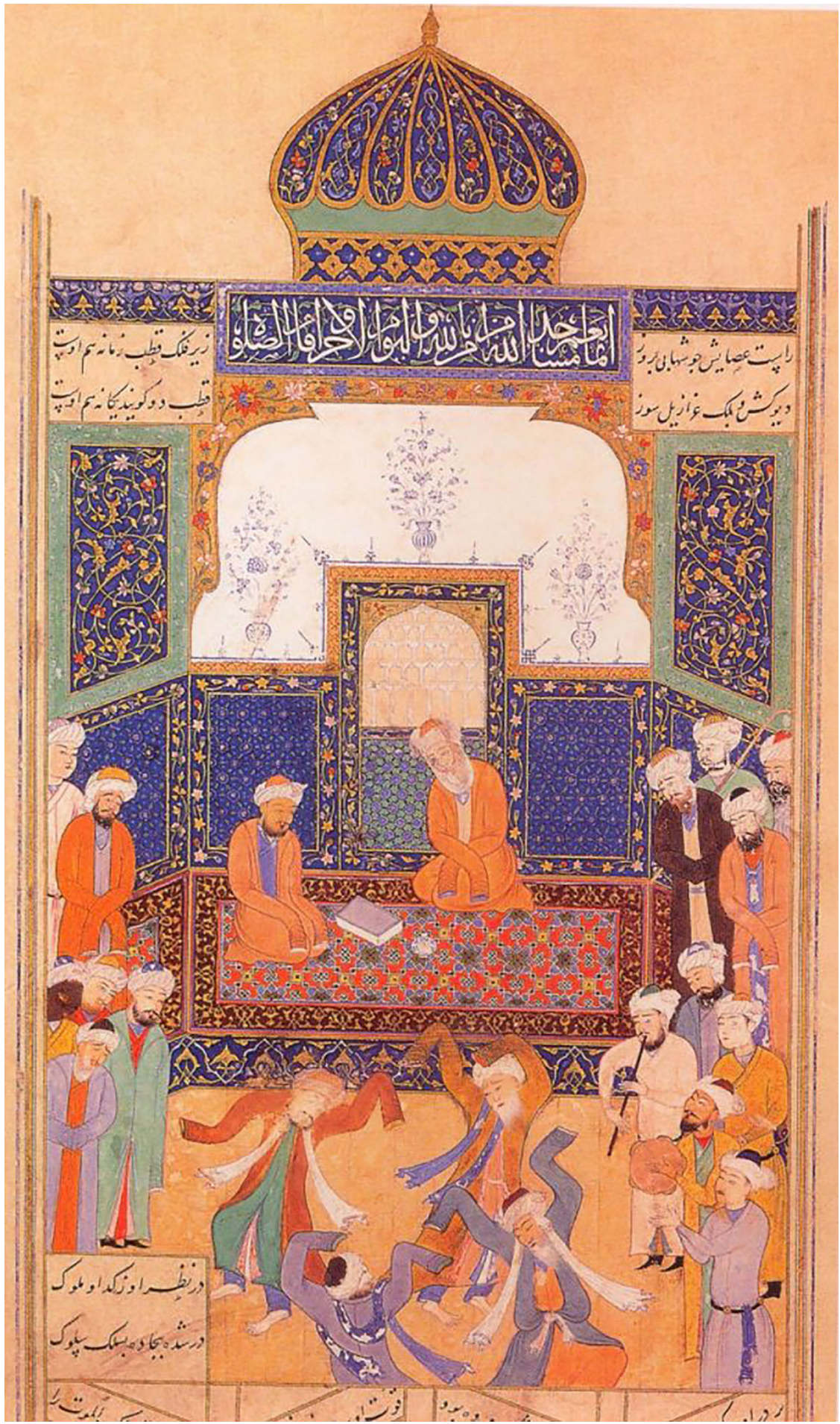

Рис. 1. Суфии проводят обряд «сама» перед шейхом Низам ад-Дином Аулия. Иллюминация рукописи, акварель. 1485 год

Fig. 1. Soufis dancing the Sama in front of cheikh Nizam al-Din Awliya Manuscript illumination, watercolour. 1485. http://religion.raftis.org/turkey/ 
лям школы суфизма. Среди них выделяются труды Абу Бакра Мухаммада аль Калабади (ум. 990) («Китаб атта аруф»), Абу-л-Касима аль Кушайри (ум. 1074) («Рисала ахкам ассама»), Ахмада Ибн Мухаммада аль Газали (ум. 1126) («Баварик ал-илма») и др.

В каждый из этих трудов помещены разделы, посвященные «слушанию» («сама»). Эта традиция не прерывалась многие столетия. Суфийские авторы не проводили различий между общеюридическими запретами ортодоксального ислама и собственными ограничениями. Постепенно опыт суфийской аргументации в защиту музыки стали использовать и музыканты авторы трактатов о музыке, преследуя более широкие музыкально-культурные цели. Средневековая полемика «сама» многообразна и значительна. В ней можно выделить сугубо практические вопросы. Они связаны с устройством, технической и ритуальной стороной «сама». Особое значение придавалось, например, соблюдению трех основных компонентов: времени, месту и «братству» - слушателям. Впервые они были сформулированы шейхом Абу-л-Касимом ал-Багдади (ум. 910). Следование этим принципам должно было уберечь суфиев от соприкосновения с обыденной жизнью и от проникновения в ритуал «сама» посторонних непосвященных людей.

Абдуррахман Джами посвятил толкованию стихов Хазрата Руми сочинение «Най-наме» (Книга ная). В XVII веке строки Джами, развивающие музыкальную философию Хазрата, избирает в качестве эпиграфа для своего «Трактата о музыке» Дервиш Али Чанги (ум. 1558) (Dervish Ali Changi):

«Что знаешь ты о звуках ранга, уда?

Тебя достаточно, ты всеисчерпывающ, о Любвеобильный,

Если нет у бездушных людей вкуса «сама»,

И если не охватила вселенную эта песнь».

Также суфии в своих трактатах уделяли вопросам единства макро- и микрокосмоса, вселенной как результату всепроникающего музыкального начала, исходящего от Всевышнего. Он наполнил своей музыкой весь мир, пространство и время. Его игра на уде заставляет всех и вся вращаться в бесконечном танце.

Основные положения суфизма - любовь к Богу-Абсолюту, презрение к богатству, стремление раскрыть тайный смысл Священного писания, поиск истины, воссоединение с Богом, отождествление Бога с природой, пантеистическое в своей основе, - противоречили мусульманской Ортодоксии.

Критику осуждения облек в поэтической форме Абдуррахман Джами (1414-1492):

«Суши мерзки, Бойся с ними встречи;

Утрачен ими облик человеческий!

$\mathrm{Bce,} \mathrm{что} \mathrm{им} \mathrm{в} \mathrm{руки} \mathrm{даешь,} \mathrm{они} \mathrm{съедят,}$

Когда хотят вредить - они вредят.

‥

Один - содеял множество чудес,

Другой - почти все таинства небес.

Так, посвящая день речам туманным,

Свой полдень он растягивал обманом» (Dzhami, 1972: 31).

В суфийской эстетике большое внимание уделяется категориям «прекрасное», «красота». Через эти эстетические категории осмысливалось божественное совершенство. Красота (есть Бог) как эстетическая категория неизменна и существует в постоянной субстации. Она несет радость, убежденность в том, что любой человек способен постичь божественную сущность. Красота мыслится в суфизме прежде всего как свойство духовное, как признак духовного совершенства.

Поскольку абсолютная красота - это Бог, каждый суфий должен стремиться к тому, чтобы во всем походить на Него. Красота Бога находит свое отражение во всем: в вещах, предметах, в творениях искусства, в человеческом облике и в душе. Не случайно в поэзии лейтмотивом идут такие понятия, как совершенство, любовь, абсолют, возвышенное, прекрасное, духовное, неизменное.

Суфизм представляет собой философизацию и эстетизацию Коранического Писания. В классическом исламе превыше всего ставятся такие нравственные добро- 
детели мусульманина, как праведность, разумность, эмоциональная сдержанность. В аскетической практике суфизма превыше всего ценится способность к полной самоотдаче, предание своей собственной воли в руки Божества, что выражается в форме экстаза, исключающей контроль разума над чувствами.

Экстаз в религиозной практике суфизма является актом обретения Бога и слияния с Ним. Имеется в виду предельное экстатическое состояние, в котором суфий мог совершенно утратить чувствительность и потерять сознание. Таким мыслился способ обретения свободы от своего «Я».

Вхождение в такое состояние - длительный процесс, требующий предельной концентрации внимания духовного мира и сосредоточенной молитвы как единственного пути, угодного Богу и ведущего к Нему. В ортодоксальном исламе молитва также расценивается как путь постижения Бога, но этот путь регламентирован определенными правилами (ритуальными, текстовыми, пластическими, интонационными); суфий же мыслил мистический путь к Богу как полное отключение своего собственного разума ради максимального самовыражения, итогом которого становится растворение духа в экстазе.

В отличие от классического трансцендентального богословия ислама, сконцентрированного вокруг идеи Бога, суфизм устанавливает в центре личность человека, его внутренний мир, обращенный к Богу. В суфизме молитва служит проявлению своего «Я» личности. Особо выделяет значение молитвы Абу Бакр Ибн-Араби (11651240):

«Молитва - единственный вид поклонения, исключающий одновременно какое-либо другое занятие. Упоминание Бога - величайшее из всех в ней заключенных речений и деяний. (...) Упоминание Бога есть самое великое в молитве, то есть упоминание, которое проистекает от Бога к рабу Его, когда Он воздает ему просимое» (Ibn-Arabi, 1987: 109).

Отличительная особенность суфийской трактовки молитвы - еe направлен- ность на восхваление, а не на прощение. Одной из этических формул хваления в поэзии суфиев становится обращение к Богу как к Возлюбленному. В стихотворении Джавада Нурбахша (1926-2008) зачитываем:

«Теперь любовь - мой культ, обряд и вера,

Друзья мои - влюбленные в Творца.

Я воле следую Его, Его примеру,

Дыханию Его я предан до конца» (Nurbahsh, 1999: 105).

В этой связи заслуживает внимания гипотеза Л. Тирольского об идейной близости поэзии суфиев и трубадуров, проявляющейся особенно ярко в акцентуации мотива Возлюбленной:

«Возлюбленная поэта становится воплощением богопроявленности, не теряя при этом своей контрастности и человечности» (Tirapol'skii, 1999: 174). Как и суфии, трубадуры играли рифмой, аллегорией, сочиняя для возлюбленной множество стихотворений.

Обращение к Богу не должно сводиться к просьбе, особенно если это выпрашивание земных благ, рассматриваемое в суфизме как аморальное действие. Если для правоверного мусульманина молитва в известной степени долг, отдаваемый ритуальному этикету, то для суфия это непосредственное выражение глубинной потребности Богообщения. Большинство суфиев признавало обязательность молитвы, идущей непосредственно от сердца, не регламентированной уставными правилами, молитвы, смысл которой кроется в сакральной силе и энергии имени Бога (в мусульманской литературе известны 99 имен Бога).

В суфизме молитва мыслится как способ и стремление уйти от всего мирского и достижения Божественного присутствия. Истинная молитва непрерывна. Ее нельзя ограничивать определенным количеством ракатов (поклонов и стоянок) или сур Корана, так как она «пронизывает все существование человека» (Shimmel', 2000: 127).

Бог - абсолютная ценность, одновременно и абсолютная красота, поэтому высшая цель молитвы - уподобление Богу. 
Но Бог так же, как и творец, часто именуемый в суфийской литературе «великим художником», создает мир как произведение искусства. Поэтому истинно верующему суфию должны быть свойственны творческие устремления, а жизнь суфия, в идеале, должна быть осуществлением призвания художника, творца Красоты.

Само собой разумеется, что создатели философской и эстетической доктрин суфизма черпали вдохновение в Божественном слове - Коране. Но чтение Корана рассматривалось суфиями скорее как средство достижения определенного медитативного состояния, как непременное условие богообщения. Поэтому в суфизме Коранический текст становится лишь отправной точкой беседы души с Богом, основой для создания персональной молитвы. Такого рода молитвы оформляются ритмизированной прозой, и в них большое значение придается повторению молитвенных коранических строф, перемежающихся аллегорическими афоризмами, как, например, в стихотворении Имадеддина Насими (1370-1417) (Nasimi, 2000):

«Коран святой, его учения - Твои слова, Святых аятов объяснение - Твои слова, Мой дух и счастье, и мучение - Твои слова,

Весь мир от сотворения - Твои слова».

Некоторые суфии склонны были противопоставлять мистическую поэзию стихотворений и священное писание Корана, отдавая предпочтение первой.

Как пишет А. Мухаммедходжаев (Muchammedchodzhaev, 1990) в работе о суфизме, чтение Корана не оказывало на них (суфиев) почти никакого эмоционального воздействия, но чтение суфийской лирической поэзии приводило их в состояние экстаза. Мусульмане применяли логические рассуждения, искали сакральный умысел божественного писания, гармоничный личному мироощущению и духовному настроению. Поэтические формы служили выражению искомого смысла, но все же идейную основу суфийской поэзии образует священный текст. В стихотворную форму суши облекали смысл аятов. Мысль о первостепенном значении коранического слова для суфийской поэзии находила выражение в изысканной метафорической форме в поэзии Джалаладдина Руми (12071273) (Rumi, 2000):

«Знай, что буква Корана - его внешность,

А за внешностью скрывается внутреннеe,

А за этим внутренним - третье,

Которое поражает разум.

Не смотри на внешность Корана,

Ибо внешность Корана - это как бы

Человеческое тело,

Внутри которого заключена душа».

Поэзия в суфизме и вообще в мусульманской культуре играла огромную роль. Слово есть наиболее совершенный инструмент духовного самораскрытия человека и совершенная форма Божественного откровения. В этой связи уместно привести высказывание Омара Хайяма (1048-1131) о том, что он «не нашел ничего лучшего, чем слово, и ничего более возвышенного, чем речь, потому что если было бы что-нибудь более замечательное, чем речь, то Всевышний Аллах обратился бы с этим к Пророку» (Khaiam, 2000: 285).

Музыка в суфизме. Наряду с поэзией в процессе мистического постижения Истины огромное значение придавалось музыке как средству раскрытия экспрессии поэтического слова. Эта эстетическая установка суфизма вступает в неразрешимое противоречие с абсолютным неприятием музыки в ортодоксальном исламе. В связи с уяснением роли музыки особый интерес представляет суфийский обряд «сама», где музыка - чисто инструментальная и вокальная - наряду с танцем служит одним из самых действенных средств достижения экстатического состояния.

Показательны в этом отношении впечатления одной из участниц данного обряда:

«Иногда вечерами мы участвовали в сессиях «сама» - практике вспоминаний, при которой исполнялась музыка. На этом собрании деревни играли на тростниковых флейтах и на тамбурине. Учитель сидел лицом к востоку, остальные сидели позади 


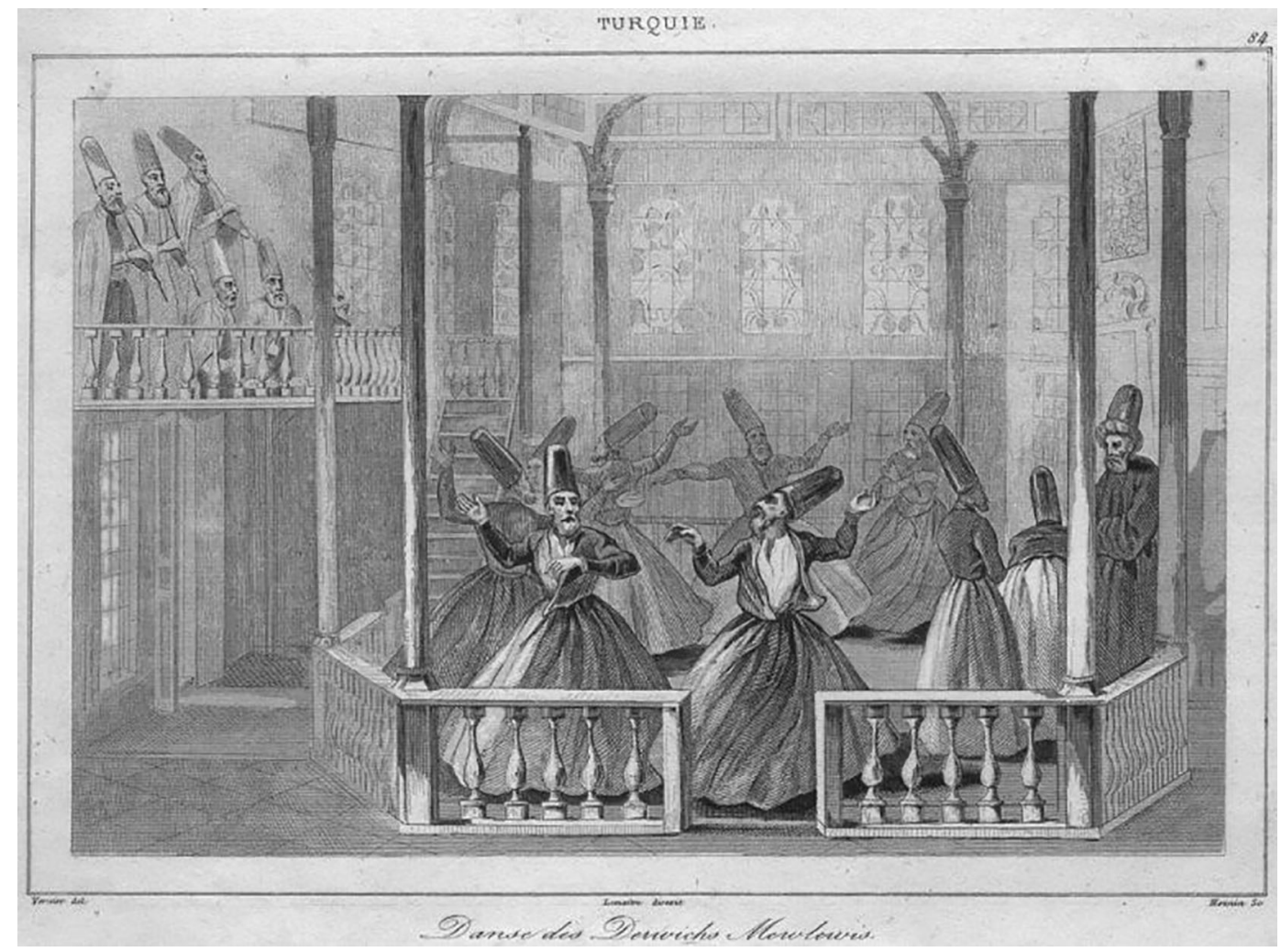

Pис. 2. Танец дервишей Мевлеви 1780 приблизительно Греция, Афины, коллекция Alkis Raftis Fig. 2. Dance of the Mevlevi dervishes Print 1780 approximately Greece, Athens, collection Alkis Raftis http://religion.raftis.org/turkey/

него. Мы производили движения головой в такт пению, а словесная форма способствовала пробужденности сердца, и укреплялась связь с вспоминаемым. Внезапно учитель встал и начал танцевать. Я удивилась, поскольку знала, что обычно это не делается. Это был танец совершенной красоты, я никогда не видела ничего подобного. Учитель, казалось, никого не замечал. Два его ближайших ученика поднялись и стали танцевать вокруг него. Когда танец закончился и музыка прекратилась, я заметила, что его лицо было мокрым от слез... Я спросила, что я должна делать, если он будет танцевать снова, не зная, должна ли присоединиться к нему или нет.

- Если Господь захочет, ты будешь танцевать, - сказал старейшина.

- И если Учитель захочет, чтобы разделила его состояние, ты заплачешь. В про- тивном случае лучше сидеть спокойно и благодарить Господа за Его щедрость» (Mak-Katcher, 2000: 8-9).

Исключительная роль музыки в этом ритуале обусловлена способностью музыки оптимизировать звучание как таковое ради укрепления смысла слушаемого текста, то есть той сакральной энергии, которой проникнуто каждое слово Корана, а также стихов на его основе. Поэт-суфий Хамза Фансури (II пол. XVI в. - I пол. XVII в.) раскрывает смысл обряда «сама» следующим образом:

«До смерти умри, растворись без следа В речение «Нет Бога, кроме Него».

Суть неразделенности моря с волной

Постигает суфий опять и опять» (Fansuri, 1988).

Собственно началом обряда считается момент вхождения его участников в мисти- 
ческий экстаз, вызванный непосредственным откликом всего существа человеческого на смысл, заключенный в том или ином божественном речении, особенно если оно произносится прекрасным голосом. Таким образом, суфийский ритуал предполагает особую эмоциональную настроенность, которая достигалась благодаря слушанию музыки или участию в танце. И.Р. Еолян выделяет две части ритуала «сама»: «Первая: строгая и уравновешенная - посвящена чтению религиозных текстов и сюжетов из жизни Пророка. Вторая: зикр (прославление Бога), кульминацией служит пантомимный раздел. Если в первой части господствует декламация стихотворных текстов, то во второй - главную роль приобретает танцевальный ритм, который становится главным средством достижения экстатического состояния. Танец непременно сопровождался музыкой» (Eolian, 1990).

Музыка же воспринималась суфиями как мистический феномен, как «весть», пришедшая из потустороннего мира. С другой стороны, музыка сама по себе мыслилась и как форма наиболее полного раскрытия любви суфия к Богу. В этом качестве музыка рассматривалась наряду с явлениями, объектами окружающей реальности, через которое происходит постижение человеком священного таинства религии. Поскольку реальный мир в восприятии суфиев представал как дисгармоничный, они стремились найти гармонию в запредельном мире. Музыка, источником своим имеющая запредельный мир, воспринималась как нечто независимое от реального мира, стоящего над ним и возвышающая душу к Богу, открывающая красоту:

«Рассказ Флейтиста - песня тростника.

Она пьянит, взывает к страсти нежно,

В ней растворяются пространства и века

Безумства и позора, веры и надежды (...)

Высокой музыки божественный язык

Лишь сердце наше различает.

Ты сердцем слушай, что поет тростник, И песнею своей тебе напоминает (...) Лишает музыка покоя
Всех тех, кто следует Пути,

$\mathrm{C}$ ее мелодией простою

Им легче трудности пройти» (Nurbahsh, 1999: 107).

Суфии в искусстве находили исходный пункт для возвышения человека над материальным миром, слияния с Богом.

Ритуал «сама». Именно музыкальные звуки оказывают наиболее сильное и непосредственное воздействие на психику человека, возбуждая его эмоции. Музыка акцентирует чувственное восприятие, которому в суфизме придавалось значение наиболее тонкого, адекватного «механизма» Богопознания, так как Бог познается не разумом: «Его нельзя видеть глазами, его надо видеть душой» (Kurbanmamadov, 1987).

«Сама» должен исполняться в то время, когда человек освобождается от жизненных моментов, он должен иметь психологическую подготовку. Проходит такое действо в просторном, спокойном месте в кругу близких людей, должна воссоздаться обстановка, способствующая возбуждать в человеке возвышенные чувства.

Ритуал «сама» и есть способ настройки души на восприятие невидимого. Настроение, душа таким образом становятся своего рода музыкальным инструментом в руках Бога. Отсюда и метафорический образ Богообщения, выраженный словосочетанием «флейтист и флейта». Так, в сочинении Джалаладдина Руми «В поисках скрытого смысла» (раздел «Поэзия и воображение») читаем:

«Если я полон дыханием, так это потому, что я - Флейта, а ты флейтист, поскольку Ты есть мое Я, о Возлюбленный, я - Самодоволен.

Возлюбленные горюют как свирели, а Любовь - Флейтист. Какие замечательные вещи вдохнет Любовь в эту флейту тела!

Флейта - проявленное, а флейтист - открытое, в любом случае моя флейта пьяна от вина Его уст. Иногда он ласкает флейту, иногда Он бьет еe! Ах! Я страдаю в руках этого сладкомелодического, разбивающего флейту флейтиста!» (Rumi, 1995).

Именно в ритуале «сама» максимально проявляется способность музыки охваты- 
вать все существо человека, пронизывать его своею звукопроницательностью. Та же мысль в поэтическом изложении Джалаладдина Руми звучит следующим образом: «сама» - это «ветер, вызывающий цветение ветвей разума, звук, раскрывающий поры существования. (..) «Сама» стал окном, открытым в твой розарий, уши и сердца возлюбленного высунулись в окно. (...) Ты не видишь, но они (суфии) способны слышать, как листья на деревьях тоже хлопают. Ты не можешь ощутить хлопанье листьев для этого тебе нужно ухо сердца, а не телесное ухо. (...) Во время «сама» суфии слышат иной звук - с Престола Господня» (Rumi, 1995: 361-362).

Кульминацией ритуала является достижение его участниками экстатического состояния, вызываемого и подготавливаемого длительным музицированием и ритуальными танцами. Ритуальный экстаз вовсе не тождественен состоянию распущенности, бесконтрольного проявления страстей; по словам суфийского мыслителя Хушхалхана Хаттака (1613-1689): «Музыка - только там, где нет ни гама, ни шума. Она настолько завладевает слушателями, что нет ни пафоса, ни дуновения» (Chattak, 1989).

Музыка в суфизме введена в обиход средств, используемых для общения с Богом. В ритуале «сама» используются ударные, духовые инструменты (на художественных миниатюрах чаще всего изображен тамбурин). Функция ударных подчеркивать остинатные ритмоформулы; духовые - флейта - ведет мелодическую линию. Музыкальная композиция выстраивается по принципу нагнетания эмоционального напряжения: ускоряется темп, учащается ритмическая пульсация, увеличивается сила звучания, расширяется звуковой диапазон.

Наряду с инструментальными эпизодами ритуал «сама» предполагает слушание и чтение нараспев коранических текстов, как оригинальных последующим разъяснением, так и в стихотворном переложении. Качество декламации принципиально не отличается от того, что принято в храмовом мусульманском богослужении.
«Красивая декламация ритмичного и звучного текста Священной книги возносила души верующих в высокие сферы и могла открыть им высший уровень понимания» (Shimmel', 2000: 29).

В некоторых суфийских орденах также исполнялись песни под тот или иной макам, который был связан с определенной эмоциональной нагрузкой для выражения конкретного переживания. К. Эрнст отмечает некую последовательность: начало с песни, обращенной к Пророку, потом песни любви, чтобы создать более напряженный эмоциональный заряд; затем песни мистического самоуничтожения; песни о пребывании Бога (Ernst, 2002).

Для суфиев каждый музыкальный тон становился музыкой небес; истинный суфий понимает каждый звук как радостную Божественную весть. Таким образом, музыкальное звучание выступает в ритуале суфиев идеальным проводником Божественной энергии, через которую Бог открывает себя всему сущему.

Заключение. В центре суфийской культуры лежит озвучивание священных текстов. Суфии использовали музыку как главный источник духовного богообщения. С помощью музыки сознание суфия освобождается от тела, а затем и от ума. В то время как в ортодоксальном исламе мусульманин при проведении богослужения является сдержанным и сосредоточенным на пропевании вслух и про себя священного текста при минимуме ритуальных телодвижений.

Музыка суфизма открывает забытые истоки и изначальные ее функции. Сегодня, когда суфийские обряды проводятся и в России, и за рубежом, важно, чтобы этот путь к первоисточникам, к глубинным смыслам понимания музыки и слова не потерял своего истинного смысла и назначения. Наше время - это время прорыва и новых свершений, поэтому здесь присутствуют музыкальные соблазны, которые нужно контролировать, понимать и воспринимать музыку в суфизме не как первопричину, а как средство и инструмент к постижению божественного писания. 


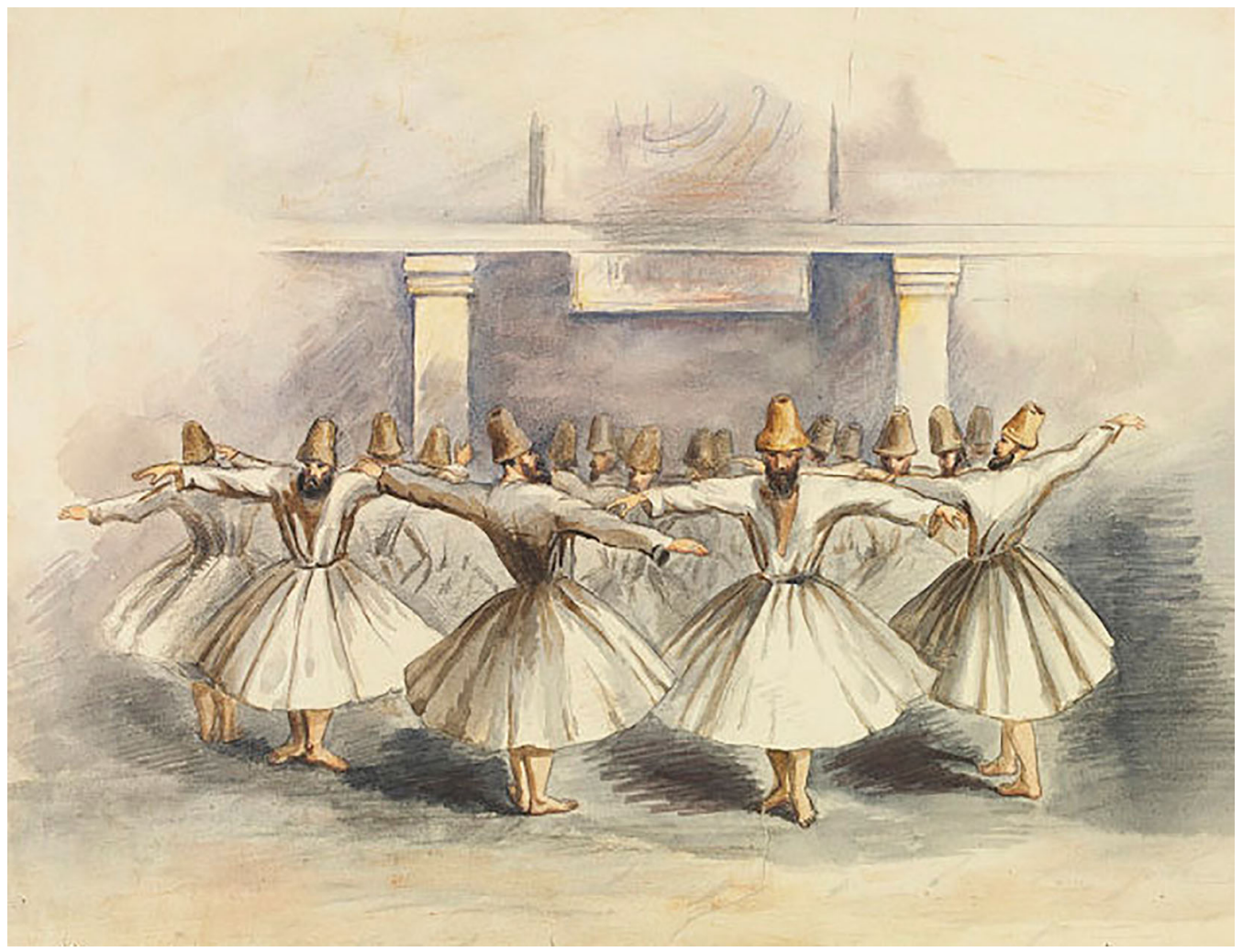

Рис. 3. С. Рид. Танец константинопольских дервишей. Акварель. 1854.

Fig. 3. S. Read. Dancing Dervishes of Constantinople. Watercolour. 1854. https://collections.vam.ac.uk/item/0148358/dancing-dervishesof-constantinople-watercolour-read-samuel-rws/

Значимость музыкального компонента лежит в неосознанном представлении о тех первородных силах, которые можно пробудить музыкальными средствами. Изучая философское осмысление музыки и слова в трактатах восточных мыслителей, приходим к выводу, что музыкально-словесный компонент в суфизме является неким таинственным, ценным атрибутом обрядовой практики.

\section{Список литературы / References}

Antologija gumannoj pedagogiki Rumi [Anthology of Humane Pedagogy Rumi]. Moscow, Amonashvili, 2000. 221 p. [in Russian].

Bertel's, E. Je. Izbrannye trudy: Sufizm i sufijskaja literatura [Selected Works: Sufism and Sufi Literature]. Moscow, Nauka, 1965. 524 p. [in Russian].

Braginskij, V. I. Hamza Fansuri [Hamza Fansuri]. Moscow, Vostochnaja literatura RAN, 1988. 343 p. [in Russian].

Chittik, U.K. V poiskah skrytogo smysla: Sufijskij put' ljubvi. Duhovnoe uchenie Rumi [In Search of Hidden Meaning: The Sufi Way of Love. Spiritual teachings of Rumi]. Moscow, Ladomir, 1995. 543 p. [in Russian].

Dervish Ali Changi, Risale ji musiki [Dervish Ali Changi, Risale ji musik]. Rukopis' IV AN RUz, inv. № 449, 1. 1b. «Ljubveobil'nyj». jepitet Boga. Rukopis’ (na pers. jaz.) 
Dzhami, A. Izbrannye proizvedenija [Selected works] v 4 tt. Dushanbe, Ifron, 1972. T. 1. 432 p.

Eoljan, I.R. Tradicionnaja muzyka Arabskogo Vostoka [Traditional music of the Arabian East]. Moscow, Muzyka, 1990. 240 p. [in Russian].

Hajjam, O. Traktat «Nauruz-name» [Khayyam O. Treatise «Nauruz-name»]. Moscow, Turan, 1994. 208 p. [in Russian].

Hismatulin, A. A. Sufizm [Sufism]. SPb, Peterburgskoe Vostokovedenie, 1999. 224 p. [in Russian].

Hushhal-Han Hattab «Dastar-Namje» (razdel «Talant k izucheniju muzyki» [«Dastar-Name» (section «Talent for studying music»] // Sufizm v kontekste musul'manskoj kul'tury [Sufism in the context of Muslim culture]. Moscow, Nauka, 1989. 341 p. [in Russian].

Ibn-Arabi. Gemmy radosti [Gems of joy] // Stepanjanc, M. T. Filosofskie aspekty sufizma [Philosophical aspects of Sufism]. Moscow, Glavnaja redakcija vostochnoj literatury izdatel'stva, 1987. Pp. 90-119. [in Russian].

Jernst, K. Sufizm [Sufizm]. Moscow, Fair-Press, 2002. 320 p. [in Russian].

Kurbanmamadov, A. Jesteticheskaja doktrina sufizma: Opyt kriticheskogo analiza [Aesthetic Doctrine of Sufism: An Experience of Critical Analysis]. Dushanbe, AN TadzhSSR, 1987. $108 \mathrm{p}$.

Mak-Katcher K. Rasskaz bednosti druga [A Friend's Poverty Tale] // Uslysh' flejtista: sufijskaja proza i pojezija [Hear the Flutist: sufi prose and poetry]. Moscow, Optimus Lajt, 2000. 184 p. [in Russian].

Man'ko, L.I. Filosofsko-jesteticheskaja sushhnost' muzyki v sufizme: na materiale muzykal'no-filosofskih issledovanij sufija Hazrata Inajjat Hana: dissertacija na soiskanie uchenoj stepeni kandidata filosofskih nauk [Man'ko, L. I. Filosofsko-jesteticheskaja sushhnost 'muzyki v sufizme: na materiale muzykal'no-filosofskih issledovanij sufija Hazrata Inajjat Hana: dissertacija na soiskanie uchenoj stepeni kandidata filosofskih naukal]. Moscow, moskovskij pedagogicheskij universitet imeni M. V. Lomonosova, 2010. 197 p. [in Russian].

Muhammedhodzhaev, A. Gnoseologija sufizma [Epistemology of Sufism]. Dushanbe, Donish, 1990. $116 \mathrm{p}$.

Nasr, S. H. Islamskoe iskusstvo i duhovnost' [Islamic art and spirituality]. Moscow, Dizajn. Informacija. Kartografija, 2009. 232 p. [in Russian].

Nurbabsh, D. Uslysh' flejtista [Hear the flutist] // Uslysh' flejtista: sufijskaja proza i pojezija [Hear the Flutist: sufi prose and poetry]. Moscow, Kogelet, 1999. 200 p. [in Russian].

Shamilli, G. B. Filosofija muzyki. Teorija i praktika iskusstva maqām [Philosophy of Music. Theory and practice of art maqām]. Moscow, Sadra, 2020. 552 p. [in Russian].

Shimmel' A. Mir islamskogo misticizma [The world of Islamic mysticism]. Moscow, Aleteja: Jenigma, 2000. 414 p. [in Russian].

Stepanjanc, M. T. Filosofskie aspekty sufizma [Philosophical aspects of Sufism]. Moscow, Nauka, 1987. 192 p. [in Russian]. 